\title{
Color changes and 5-hydroxymethyl furfural formation in zile pekmezi during storage
}

\author{
By Ilkay Tosun \\ Ondokuz Mayis University, Faculty of Engineering, Department of Food Engineering, \\ Samsun, Turkey, E-mail: itosun@omu.edu.tr
}

\section{RESUMEN}

Cambios del color y formación de 5-hidroximetilfurfural durante el almacenamiento de zile pekmezi.

El Zile pekmezi (pekmez duro blanco) es un alimento turco tradicional que se produce a partir del zumo del uva. El color, el sabor y el contenido en 5-hidroximetilfurfural (HMF) son los parámetros de calidad más importantes en el Zile pekmezi. El pardeaminto es el problema más común que afecta a la calidad del pekmez.

En este estudio se evalúa la cinética de formación del HMF determinándose los ordenes de reacción, las constatntes de formación y la energía de activación así como las variaciones en las diferencias de color $(\Delta \mathrm{E})$ en Zile Pekmezi, almacenado a 55, 65 y $75^{\circ} \mathrm{C}$ durante 9 dias.

Los resultados indicaron que la formación de HMF y la variación del color durante el proceso termal del Zile pekmezi siguieron una cinética de orden cero. Las energìas de activación calculadas para HMF y el $\Delta \mathrm{E}$ fueron de $158.63 \mathrm{~kJ} \mathrm{~mol}^{-1}$ y $40.04 \mathrm{~kJ} \mathrm{~mol}^{-1}$, respectivamente.

PALABRAS-CLAVE: Color - Hidroximetilfurfural - Pekmez Zile Pekmezi.

\section{SUMMARY}

Color changes and 5-hydroxymethyl furfural formation in zile pekmezi during storage.

Zile pekmezi (white hard pekmez) is a traditional Turkish food which is produced from grape juice. Color, flavour and 5-hydroxymethyl furfural (HMF) contents are the most important quality parameters in Zile pekmezi. Browning is the most common quality problem in pekmez.

In this study, reaction orders, rate constants and activation energies were evaluated for HMF formation and color difference $(\Delta \mathrm{E})$ variation in Zile pekmezi stored at 55,65 and $75^{\circ} \mathrm{C}$ along 9 days.

The results indicated that $\mathrm{HMF}$ formation and $\Delta \mathrm{E}$ variation during thermal processing of Zile pekmezi followed zero order reaction kinetics at 55,65 and $75^{\circ} \mathrm{C}$. Calculated activation energy for $\mathrm{HMF}$ and $\Delta$ Ewere $158.63 \mathrm{~kJ} \mathrm{~mol}^{-1}$ and $40.04 \mathrm{~kJ} \mathrm{~mol}^{-1}$, respectively.

KEY-WORDS: Color - Hydroxymethylfurfural - Pekmez Zile Pekmezi.

\section{INTRODUCTION}

Color plays an important role in appearance, processing, and acceptability of food materials. Color is perceived as part of the total appearance, which is the visual recognition and assessment of the surface and subsurface properties of the object (Ahmed et al., 2002).

For many products, browning is desirable. However, in other foods browning is undesirable. Browning is the most common quality problem in pekmez. Color, flavour and HMF contents are the most important quality parameters in Zile pekmezi.

White hard pekmez (Zile pekmezi) is particularly produced from grape juice. The acidity of grape juice is decreased with the application of $\mathrm{CaCO}_{3-}$ containing special white soil, or $\mathrm{CaCO}_{3}$ alone, and the grape juice is left to sediment. Acid-decreased and clarified grape juice is concentrated to the desired Brix degree under atmosferic pressure, or by a vacuum method. After addition of the white of an egg, soapwort extract, former pekmez, or powdered sugar as bleaching agents, and pectin as gelling agent, the concentrated grape juice is stirred and beaten (Tosun and Ustun, 2003).

Nonenzymatic browning reactions of pekmez occur either by caramelization or Maillard reaction. Maillard reaction takes place between amino and carbonyl compounds. It results in undesirable changes and is followed by the formation of intermediates such as 5-hydroxymethyl furfural (HMF), and finally brown pigment formation (Bozkurt et al., 1999).

The color measurement can be used in an indirect way to estimate colored compounds of food, since it is simpler and faster than chemical analysis. Tristimulus color measurements have been succesfully employed to calculate the rate constants and activation energies for nonenzymatic color development (López et al., 1997; Bates et al., 1998; Bozkurt et al., 1999).

Many studies concerned with the kinetics of the Maillard reactions, pigment and color degradation (Bates et al.,1998; Bell et al., 1998; Buglione and Lozano, 2002). These studies major finding is that Maillard reactions follow zero order reaction kinetics (Bates et al., 1998; Bozkurt et al., 1999).

The purpose of this work was to determine the HMF formation and changes in color parameters in Zile pekmezi (white hard grape pekmez) during storage and evaulate reaction orders and the rate constants for HMF formation and $\Delta \mathrm{E}$. 


\section{MATERIALS AND METHODS}

\subsection{Samples}

Zile pekmezi samples produced by a commercial factory in Tokat, Zile, were used. Upon production, the samples arriving to the laboratory were identified by several physical and chemical properties. Samples were placed into glass tubes in duplicate and closed tightly and held in temperature-controlled laboratory ovens at three different temperatures $\left(55,65\right.$ and $\left.75^{\circ} \mathrm{C}\right)$. Analyses were made in duplicate and average values were used. Initially, Zile pekmezi had a pH 5.53, Brix 83.20 o, total sugar $76.9 \%$, invert sugar $68.4 \%$ and crude protein $2.41 \%$.

\subsection{Apparatus}

HMF was determined with a JASCO UV-Visible V-530 spectrophotometer. Color was evaluated by means of a reflectance colorimeter (CR 300, Chromometer, Minolta, Japan).

\subsection{Methods}

HMF was determined following the procedure described by the IFFJP (1964), based on the colorimetric reaction between barbituric acid, p-toluidine and HMF, forming a red colored complex. The intensity of the red colour was measured at 550 $\mathrm{nm}$ with the spectrophotometer.

Color was evaluated by measuring Hunter $\mathrm{L}$ (lightness, 100:White, 0: Black), a (+, red; -, green), b (+, yellow; -, blue) parameters by means of the colorimeter. A white tile (No: 21733001) was used to standardize the instrument. Hue angle $(\mathrm{H})$ and color difference $(\Delta \mathrm{E})$ were calculated according to the following equations:

$$
\begin{aligned}
H & =\tan ^{-1}(\mathrm{~b} / \mathrm{a}) \\
\Delta \mathrm{E} & =\left(\Delta \mathrm{L}^{2}+\Delta \mathrm{a}^{2}+\Delta \mathrm{b}^{2}\right)^{1 / 2}
\end{aligned}
$$

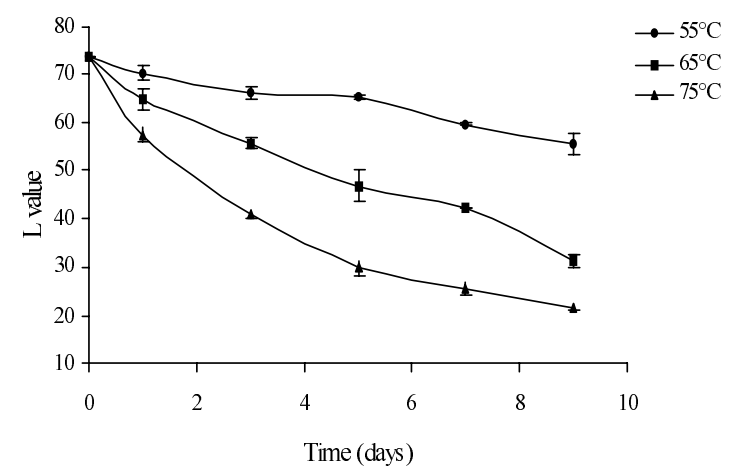

Figure 1

Change in Hunter L during storage at different temperatures.

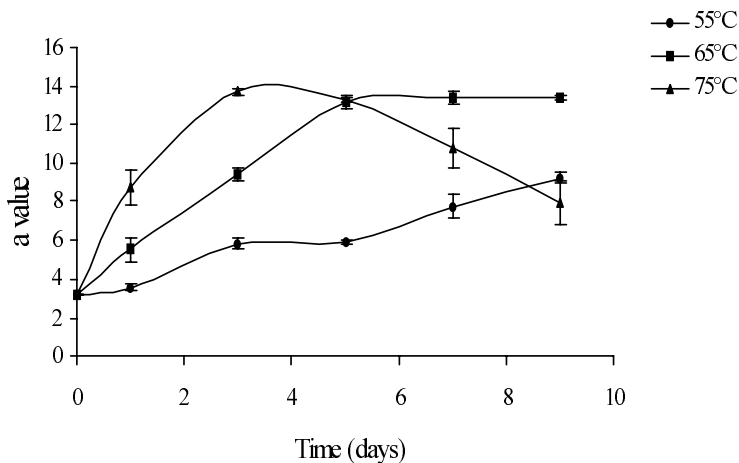

Figure 2

Change in Hunter a during storage at different temperatures

where $\Delta \mathrm{a}=\mathrm{a}-\mathrm{a}_{0} ; \Delta \mathrm{b}=\mathrm{b}-\mathrm{b}_{0} ;$ and $\Delta \mathrm{L}=\mathrm{L}-\mathrm{L}_{0}$. Subscript ' 0 ' indicates initial color.

\subsection{Statistical analysis}

Regression analyses were performed to determine reaction order and rate constants for HMF and $\Delta \mathrm{E}$. Correlation analyses were performed to determine the relationship between color parameters and HMF during storage at different temperatures. Both regression and correlation analyses were carried out with SPSS 11.0 statistical package programme.

\section{RESULTS AND DISCUSSION}

This study was carried out along 9 days at three different temperatures $\left(55,65\right.$ and $\left.75^{\circ} \mathrm{C}\right)$. Changes in color of samples during storage are shown in Figures 1-5. As can be seen, lightness $L$ and hue angle decreased during storage. As storage temperature is increased, $L$ value and hue angle decreased. These results revealed that the rate of the browning reaction increased with increasing temperature. Decreased lightness indicated browning reaction.

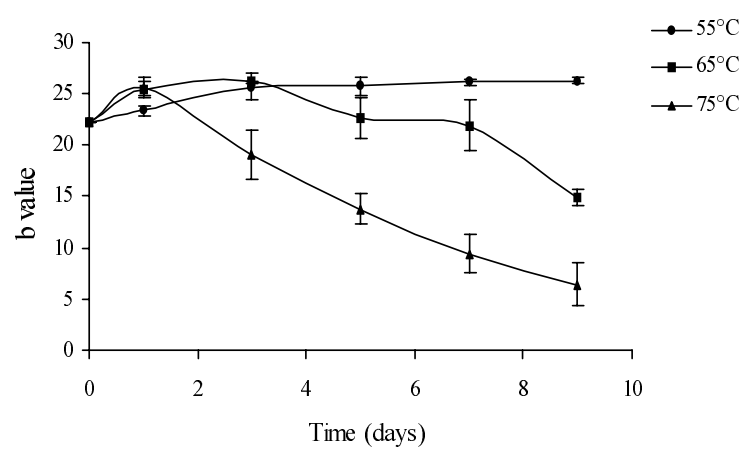

Figure 3

Change in Hunter b during storage at different temperatures 


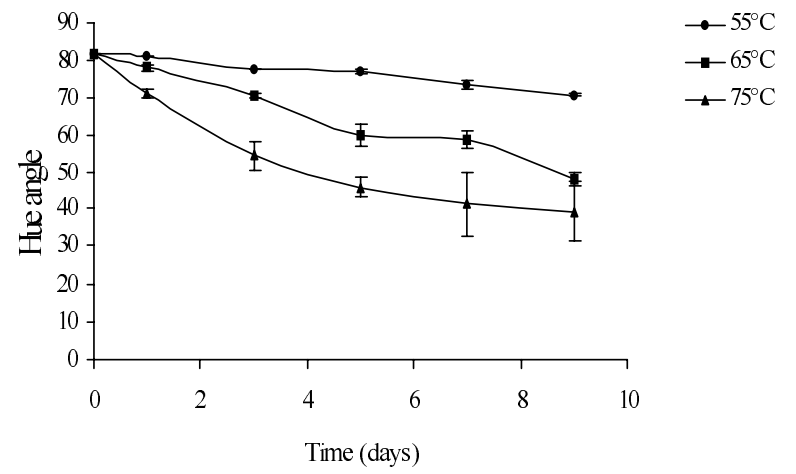

Figure 4

Change in Hue angle during storage at different temperatures

Redness (+a) showed different behaviour at different temperatures. While yellowness $(+b)$ tends to stabilize from the third day at $55^{\circ} \mathrm{C}$, it decreased at 65 and $75^{\circ} \mathrm{C}$ during storage (Figure 3 ).

The HMF content increased with temperature and heating time (Figure 6). The following equation was used to fit both $\mathrm{HMF}$ formation and $\Delta \mathrm{E}$ data by using linear regression analysis:

$$
\mathrm{C}-\mathrm{C}_{0}=\mathrm{kt}
$$

where $\mathrm{C}$ is the concentration atagiven time, $\mathbf{C}_{0}$ is the concentration at time zero, $\mathrm{k}$ is the rate constant and $\mathrm{t}$ is the time.

Calculated rate constants for HMF formation are given in Table I. HMF formation during thermal processing of Zile pekmezi followed zero order reaction kinetics at 55,65 and $75^{\circ} \mathrm{C}$. The kinetic rate constant values increased when increasing heat treatment temperatures. The reaction order for HMF accumulation of boiled grape juice (pekmez) was found to be zero (Bozkurt et al., 1999) and 0.3 (Gögüs et al., 1998).

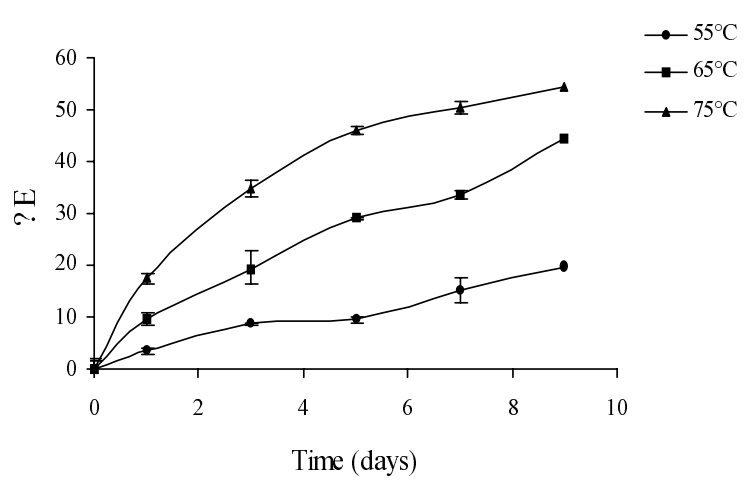

Figure 5

Change in color difference during storage at different temperatures

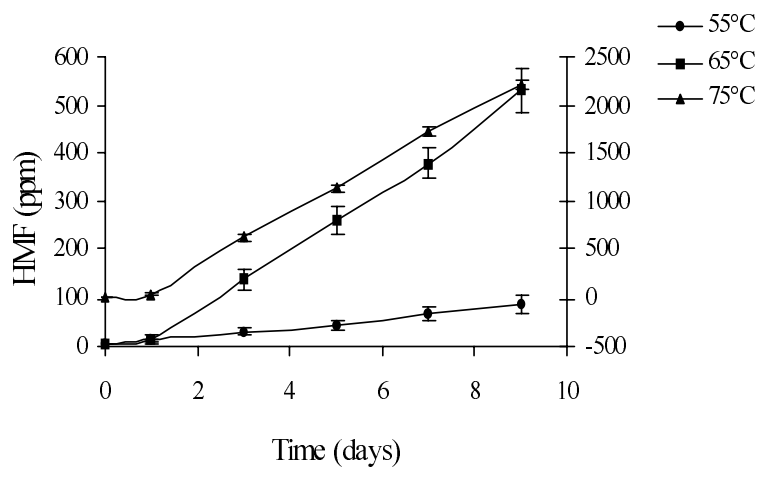

Figure 6

Change in HMF content during storage at different temperatures

The Arrhenius relationship was applied to estimate activation energies. The Arrhenius equation relating rate constant with temperature is represented by:

$$
k=k o e^{(-E a / R T)}
$$

where $\mathrm{k}$ is the rate constant, ko is the constant independent of temperature (frequency factor), Ea is the activation energy, $\mathrm{R}$ is the universal gas constant, and $\mathrm{T}$ is the absolute temperature.

Calculated activation energy for HMF formation and $\Delta \mathrm{E}$ variation are given in Table $\mathrm{I}$. As shown in the Table, the activation energy for HMF formation in Zile pekmezi was $158.63 \mathrm{~kJ} \mathrm{~mol}^{-1}$. Activation energies reported for color development due to Maillard reactions are generally in the range 65 to $170 \mathrm{~kJ}$ $\mathrm{mol}^{-1}$ (Lee et al., 1984; Baisier and Labuza, 1992; Bates et al., 1998; Bozkurt et al., 1999).

Bozkurt et al. (1999) calculated the activation energy of HMF in pekmez as $103 \mathrm{~kJ} \mathrm{~mol}^{-1}$. As seen, the calculated activation energy in Zile Pekmezi was higher than that reported by Bozkurt et al. (1999), but it was similar to other researchers' reports. This difference may be due to the composition and structure of food systems. Zile pekmezi is rich in sugar and protein. Bates et al. (1998) reported that as the water content of food is decreased, the activation energy increases.

Color differences $(\Delta \mathrm{E})$ increased linearly with treatment time at 55 and $65^{\circ} \mathrm{C}$ and followed during storage zero order equation (Eq.3), but didn't follow at $75^{\circ} \mathrm{C}$. It can be observed that the fittings are not very well correlated, but at an acceptable level is obtained. Similar results were reported for brown pigment formation by Carabasa-Giribet and Ibarz-Ribas (2000) who studied it for aqueous glucose systems.

Calculated activation energy of $\Delta \mathrm{E}$ in Zile Pekmezi was $40.04 \mathrm{~kJ} \mathrm{~mol}^{-1}$. López et al. (1997) who studied it on hazelnut obtained that the activation 
Table I

Rate constant and activation energy values (mean $\pm \mathrm{SD}$ ) for HMF and $\Delta \mathrm{E}$ at different temperatures

\begin{tabular}{ccccc}
\hline Parameters & Temperature $\left({ }^{\circ} \mathbf{C}\right)$ & $\mathbf{k}$ (concentration day $\left.{ }^{-1}\right)$ & $\mathbf{R}^{2}$ & Ea $\left(\mathbf{k J ~ m o l}^{-1}\right)$ \\
\hline $\mathrm{HMF}$ & 55 & $9.07 \pm 0.67$ & 0.996 & $158.63 \pm 3.73$ \\
& 65 & $59.49 \pm 0.41$ & 0.989 & $\mathrm{R}^{2}=0.997$ \\
& 75 & $255.64 \pm 0.93$ & 0.993 & \\
\hline$\Delta \mathrm{E}$ & 55 & & & \\
& 65 & $1.94 \pm 0.14$ & 0.964 & $40.12 \pm 5.24$ \\
& 75 & $4.15 \pm 0.21$ & 0.987 & $\mathrm{R}^{2}=0.830$ \\
& & $4.49 \pm 0.17$ & 0.910 & \\
& & & \\
\hline
\end{tabular}

Table II

Correlation matrix of color parameters and HMF value

\begin{tabular}{llllll}
\hline & L & a & b & Hue & $\Delta E$ \\
\hline L & 1.00 & & & & \\
a & $-0.802^{* *}$ & & & & \\
b & $0.809^{* *}$ & -0.367 & & & \\
Hue & $0.995^{* *}$ & $-0.781^{* *}$ & $0.850^{* *}$ & & \\
$\Delta \mathrm{E}$ & $-1.000^{* *}$ & $0.805^{* *}$ & $-0.803^{* *}$ & $-0.994^{* *}$ & \\
HMF & $-0.859^{* *}$ & 0.409 & $-0.940^{* *}$ & $-0.879^{* *}$ & $0.856^{* *}$ \\
& & & & & \\
& & & & & \\
\hline${ }^{* *}$ Correlation is significant at the 0.01 level. & & & & \\
\end{tabular}

energy of $\Delta \mathrm{E}$ in hazelnut was between 28 and $39 \mathrm{~kJ}$ $\mathrm{mol}^{-1}$. On the other hand, Bates et al. (1998) working with a Starch-Glucose-Lysine system reported an activation energy of $\Delta \mathrm{E}$ of $66.5 \mathrm{~kJ} \mathrm{~mol}^{-1}$. As a result, calculated activation energy of $\Delta \mathrm{E}$ in Zile Pekmez was below Bates et al. (1998), and similar to that obtained by López et al. (1997).

In order to assess relationships between various color parameters and HMF, Pearson correlation coefficients were calculated. It can be found that there were negative correlations between hue angle $\left(r=-0.879^{\star *}\right), L\left(r=-0.859^{* *}\right)$ and $b\left(r=-0.940^{* *}\right)$ values with HMF values $(p<0.01)$, and were positive between $\Delta E\left(r=0.856^{\star *}\right)$ and $a(r=0.409)$ values with HMF values $(p<0.01)$ during storage (Table II). As show in Table II, $\Delta \mathrm{E}$ had a highly negative correlation with lightness.

\section{CONCLUSSION}

Results indicated that temperature is an important parameter affecting the quality of Zile pekmezi which should have a maximum HMF content of $25 \mathrm{ppm}$. L value and hue angle decreased while $\triangle \mathrm{E}$ and $\mathrm{HMF}$ values increased during storage. HMF formation during thermal processing of Zile pekmezi followed zero order reaction kinetics at 55, 65 and $75^{\circ} \mathrm{C}$. Calculated activation energy for HMF was $158.63 \mathrm{~kJ} \mathrm{~mol}^{-1}$.

Negative correlations were found between hue angle, $L$ and $b$ values with $\operatorname{HMF}(p<0.01)$, and 
positive correlation between $\Delta \mathrm{E}$ and $\mathrm{HMF}$ values $(p<0.01)$ were obtained during storage.

\section{REFERENCES}

Ahmed, J., Kaur, A. and Shivhare, U. (2002). Color degradation kinetics of spinach, mustard leaves, and mixed puree. J. Food Sci., 67, 1088-1091.

Baisier, W.M. and Labuza, T.P. (1992). Maillard browning kinetics in a liquid model system. J. Agric. Food Chem., 40, 707-713.

Bates, L., Ames, J.M., MacDougall, D.B. and Taylor, P.C. (1998). Laboratory reaction cell to model Maillard color development in a starch-glucose-lysine system. $J$. Food Sci., 63, 991-996.

Bell, L.N., White, K.L. and Chen, Y.H. (1998). Maillard reaction in glassy low-moisture solids as affected by buffer type and concentration. J. Food Sci., 63, 785-788.

Bozkurt, H., Gögüs, F. and Eren, S. (1999). Nonenzymic browning reactions in boiled grape juice and its models during storage. Food Chem., 64 , 89-93.

Buglione, M. and Lozano, J. (2002). Nonenzymatic browning and chemical changes during grape juice storage. J.Food Sci., 67, 1538-1543.
Carabasa-Giribet, M. and Ibarz-Ribas, A. (2000). Kinetics of colour development in aqeous glucose systems at high temperatures. J. Food Engineering, 44, 181-189.

Gögüs, F., Bozkurt, H. and Eren, S. (1998). Kinetics of Maillard reactions between the major sugars and amino acids of boiled grape juice. Lebensm.-Wiss.u.-Technol., 31, 196-200.

IFFJP (International Federation of Fruit Juice Producers Methods) (1964). Analsen-analyses; Fruit-Union Suisse Assoc. Svizzera Frutta Zug Switzerland, 12, 1-4.

Lee, C.M., Sherr, B. and Koh, Y-N. (1984). Evaluation of kinetic parameters for a glucose-lysine Maillard reaction. J. Agric. Food Chem., 32, 379-382.

López, A., Pique, M.T., Boatella., J., Romero, A., Ferrán, A. and García, J. (1997). Influence of drying conditions on the hazelnut quality: III. Browning. Drying Technology, $15,989-1002$.

Tosun, I. and Ustun, N.S. (2003). Nonenzymic browning during storage of white hard grape pekmez (Zile pekmezi). Food Chem., 80, 441-443. 